\title{
TITLE:
}

\section{INTRODUCTION TO DR. ABE'S STUDIES ON THE FAMILY PERIDINIDAE}

AUTHOR(S):

Saito, Minoru

\section{CITATION:}

Saito, Minoru. INTRODUCTION TO DR. ABE'S STUDIES ON THE FAMILY PERIDINIDAE. Publications of the Seto Marine Biological Laboratory. Special Publication Series 1981, 6: vii-viii

ISSUE DATE:

1981-02-25

URL:

http://hdl.handle.net/2433/176463

RIGHT: 


\section{INTRODUCTION TO DR. ABE'S STUDIES ON THE FAMILY PERIDINIDAE}

The main part of the investigation made by the late Dr. T. H. Abé includes a series of the studies in the morphology and classification of the armoured dinoflagellates. He initiated his study in this field in 1925 and really continued it until his death in 1971. He collected his material from various sea areas around Japan, particularly neighbouring waters of Asamushi and Shimoda, by himself or through the aid of his colleagues, and carried out his study on freshly collected living cells and formaline-fixed ones by ordinary microscopy.

Dr. Abés attention was focussed on the structural relations of the thecal plates of the ventral area encircling the flagellar pore. He examined, described and figured, beside the general cell structure, the major thecal characters, the features and arrangement of epithecal and hypothecal plates, the features of the girdle encircling the cell surface transversely, the shape of apical and antapical appendages and the plate pattern of the ventral area. His observations were keen and his drawings were exquisite and self-explanatory, viewed from almost all directions, ventral and dorsal, sinistral and dextral, apical and antapical, basing on intact cells, as well as on partially split cells by gently pressing when necessary. It is to be noted that he had realized the significance of the plate pattern of the ventral area in classifying this group and had made efforts to reconstruct the complicate structure of the ventral area and to illustrate the elements as they were originally, as far as possible. A part of the results of his extensive work was published during the period of 1927-1941 in six papers shown elsewhere in the list of his publications. In regard to this point, H. W. Graham (1942) has mentioned: "Abé (1936) has begun a reclassification of the genus Peridinium on the basis of the structure of this region."

Dr. Abé published another four papers on Podolampidae, Prorocentridae and Dinophysidae among the armoured dinoflagellates serially in the Publications of the Seto Marine Biological Laboratory (1966-1967). In these papers, he extended his work into the lower groups of the dinoflagellates. However, a large amount of descriptions already prepared by him on the rest groups have been left unpublished. The manuscripts of the most voluminous part of his work, dealing with the Family Peridinidae, have already been type-written, and the figures have been mostly inked in. Still, the introductory remarks and the list of references are wanting, and over eighty figures are remaining in pencil drawing. These do not curtail the value of his work, but, in order to bring them into printing, the pencil works of the figures should be strengthened, the explanations of figures in pencil drawing should be added and the figures should be arranged and placed to the appropriate part of the description.

In the course of preparation of these manuscripts for publication, the writer took particularly the following three points into consideration:

1. The original descriptions by Dr. Abé should be kept untouched as far as pos- 
sible. Strengthening the indistinct pencil works is limited to just strengthening, not making any refinements nor corrections.

2. Some figures were rather poor, which were drawn in a very early period of his investigation (1925). They should also be included in this monograph, partly as a memorial to his early period of work.

3. Among the descriptions proposing new species, the description for one species does not accompany figures, except that of the ventral area, that could not be found from the piles of manuscripts by all means. Dr. Abé has prepared a new specific epithet, but this speciesis presented in this monograph as Peridinium sp.

By now, research techniques, including the electron microscopy, have been highly advanced, and further E. Balech (1974) transferred the majority of marine species from the genus Peridinium into the genus Protoperidinium. The results of recent works like this are not referred to the description and discussion of this monograph, since they may impose large amendments of the original manuscripts of Dr. Abé. Much remains still to be done. Yet, despite these shortcomings, the results of Dr. Abé's observations brought here in this issue are thorough enough to be evaluated as having attained to the highest level in the field of protozoan morphology, and the descriptions in their systematics as well. In this sense, this monograph will mark a milestone in the field of protozoology.

Minoru Saitô.

September 29, 1980.

Yokohama. 